\title{
Paradoxes of Populism during the Pandemic
}

\author{
Rogers Brubaker ${ }^{\dagger}$ \\ Published in Thesis Eleven, November 3, 2020: \\ https://journals.sagepub.com/doi/10.1177/0725513620970804
}

\begin{abstract}
Populist protests against Coronavirus-related restrictions in the US appear paradoxical in three respects. Populism is generally hostile to expertise, yet it has flourished at a moment when expertise has seemed more indispensable than ever. Populism thrives on crisis and indeed often depends on fabricating a sense of crisis, yet it has accused mainstream politicians and media of overblowing and even inventing the Corona crisis. Populism, finally, is ordinarily protectionist, yet it has turned anti-protectionist during the pandemic and challenged the allegedly overprotective restrictions of the nanny-state. I address each apparent paradox in turn before speculating in conclusion about how populist distrust of expertise, antipathy to government regulation, and skepticism toward elite overprotectiveness may come together - in the context of intersecting medical, economic, political, and epistemic crises - in a potent and potentially dangerous mix.
\end{abstract}

${ }^{\dagger}$ Department of Sociology, UCLA. brubaker@soc.ucla.edu. 


\section{Paradoxes of Populism during the Pandemic}

The initial wave of populist protests against the Corona lockdown in the US, already receding in mid-May as restrictive measures began to be lifted, was completely overtaken in June by the vastly larger wave of protest sparked by the killing of George Floyd. Yet just as the pandemic itself remains very much with us, despite the widespread desire to declare it over and get on with normal life, so too do the underlying tensions brought into focus by the spring antilockdown protests. These tensions - over expertise, crisis, and protection - are likely to loom even larger in the months ahead.

The protests against Corona restrictions, at first glance, appear paradoxical in three respects. Populism is generally hostile to expertise, yet it has flourished at a moment when people have been looking to scientists for tests, treatment, and vaccines, to public health professionals for guidance, and to medical experts for care. Populism thrives on crisis and indeed often depends on fabricating a sense of crisis, yet populist arguments have accused mainstream politicians and media of overblowing and even inventing the Corona crisis. Populism, finally, is ordinarily protectionist, yet it has turned anti-protectionist during the pandemic and challenged the allegedly overprotective restrictions of the nanny-state. I address each apparent paradox in turn before speculating in conclusion about how populist distrust of expertise, antipathy to government regulation, and skepticism toward elite overprotectiveness may come together - in the context of intersecting medical, economic, political, and epistemic crises - in a potent and potentially dangerous mix. 
A few clarifications and qualifications are in order. First, 'populism' may be too solid a word for what I will be discussing. It risks reifying what I prefer to think of as a discursive and stylistic repertoire, a set of tropes, gestures, and stances. ${ }^{1}$ Second, in keeping with this understanding of populism, I do not discuss populist movements, parties, or leaders; I am concerned rather with a certain way of talking, a loose complex of tropes and gestures. Third, I will be concerned almost exclusively with the US. Some of my themes have parallels elsewhere, but much of my argument reflects the distinctiveness of the American experience of the pandemic and the distinctive salience of anti-intellectualism, libertarian anti-statism, and myths of self-reliance in American political culture. Lastly, although I focus on the US, I will not say much about Trump. I seek rather to characterize a broader current of populist discontent, though obviously one with which Trump has aligned himself at key moments and one to which he has given additional impetus.

\footnotetext{
${ }^{1}$ I have argued elsewhere that populism is most fruitfully understood as a discursive and stylistic repertoire involving varying elaborations and permutations of a number of elements. The core element is the claim to speak and act in the name of 'the people,' construed in a 'twofold opposition, at once vertical and horizontal, against "those on top" (and sometimes also "those on the bottom") on the one hand, and against an alien or threatening "outside" on the other, generally in such a way that economic, political, and cultural elites are represented as being "outside" - or at least different or "other" - as well as "on top." Other elements include majoritarianism, which asserts the interests, rights, and will of "the majority" against those of minorities (including those on the top, those on the bottom, and those on the margins); antiinstitutionalism, which delegitimizes the complex workings of mediating institutions in the name of an ideology of immediacy, transparency, and directness; protectionism - economic, securitarian, or cultural - which claims to protect "the people" against threats from above, from below, and from outside, threats that are often represented in the language of crisis; a communicational style that claims to favor plain speaking, common sense, and authenticity against intellectualism and political correctness; and antagonistic re-politicization, which claims to reassert democratic authority over depoliticized domains of social life.' (I take this summary from Brubaker 2020:60; I develop the argument in greater detail in Brubaker 2017a: 360-367.)
} 


\section{Expertise}

I begin, then, with expertise. How could there be much room for populism, and specifically for its characteristic attacks on experts and expertise, at a moment when experts and expertise have seemed more indispensable than ever? ${ }^{2}$

The pandemic has obviously increased the demand for experts, not only as advisors to decision-makers, but also as communicators to the public. It has dramatically increased the influence, the visibility, and the accessibility of virologists, infectious disease epidemiologists, and other public health experts. But precisely this influence, this visibility, and this accessibility have made that expertise vulnerable to populist attack.

The paradox of expertise, in short, is only an apparent paradox. Expertise is vulnerable to challenge and attack not in spite of its being indispensable but because it is indispensable - and because the stakes are so high. There is nothing new about this vulnerability. The inexorably increasing 'scientization of politics,' as Gil Eyal (2019: 97) put it, necessarily brings in its train the 'politicization of science.’ Expertise is continually called upon to help rationalize and legitimize policy decisions - decisions that necessarily 'advantage some groups and disadvantage others' (Eyal 2020). In the present crisis, decisions justified with reference to expertise have devastated and existentially threatened some while merely inconveniencing others. So it's no surprise that expertise would come under attack.

\footnotetext{
${ }^{2}$ Populism is not consistently opposed to expertise per se. As an anti-institutional and antiestablishment political style, populism challenges experts and forms of expertise associated with the establishment and its institutions, while at the same time often appealing to counter-experts (Ylä-Anttila, 2018; Brandmayr, 2019; Schulman, 2020).
} 
The influence of epidemiologists has indeed been truly unprecedented. Never before, arguably, has so narrow a network of experts exerted so decisive and so incalculably far-reaching an effect on the course of world events, upending the lives of billions and plunging the world economy into its deepest crisis since the Great Depression.

The lockdowns initially enjoyed very broad public support, and restrictive measures still enjoyed the support of a substantial majority at least until early May (Washington Post-Ipsos 2020). But as they moved through their second and into their third month, and as the medical emergency became less immediately and urgently threatening, these drastic measures - and the expert advice on which they were predicated - became an irresistible focal point for popular anger and frustration. That anger and frustration were overshadowed in June by the anger and frustration expressed in protests against police brutality and racism. But the anger and frustration about the lockdowns have not gone away, even as strict lockdown measures were relaxed - and they have indeed found new targets since the summer as new restrictions have been imposed in response to the surge in infections. In the context of an unprecedented economic crisis, the political significance of that anger and frustration is likely to increase rather than diminish, and 'the experts' - as well as the politicians who listened to them - are likely to be blamed for the economic carnage occasioned by the lockdowns.

Besides the extraordinarily concentrated, consequential, and visible influence of expertise, I want to highlight two additional factors. The first is the gap between what people know relatively directly from common sense and personal experience, and what people know about from expert models and projections. This epistemic gap gives rise to what I will call the experiential challenge to expertise. The second factor is the hyper-accessibility of expertise, which gives rise to a participatory challenge. 
Consider first the experiential challenge. Populism tends to valorize common sense and concrete personal experience, and it tends to be suspicious of abstract and experience-distant forms of knowledge (Saurette and Gunster 2011). It's easy to see how the Corona crisis has activated this suspicion. The extreme unevenness of the pandemic in geographic and social space has created a huge discrepancy between what many people have seen in their own local surroundings - few illnesses, fewer deaths, and empty hospitals, for example - and the dire picture reported from early hotspots or projected for the country as a whole. At the end of May, nearly half of America's approximately 3,000 counties had not reported a single Covid-19 death, and $80 \%$ had reported fewer than 10 deaths. ${ }^{3}$ Many residents of rural and small-town America and even many residents of metropolitan America - could easily think that the crisis was overblown and the lockdown unnecessary.

The widely publicized disproportionate vulnerability of African Americans, Latinos, and Native Americans, of the urban poor, of the incarcerated, and of immigrant workers in meatpacking plants may reinforce the tacit or explicit sense, on the part of many residents of low-prevalence areas, that that this is not 'their' pandemic, but one that afflicts others. ${ }^{4}$ Anti-

\footnotetext{
${ }^{3}$ Calculated from county-level data as of May 28, 2020, downloaded from https://usafacts.org/visualizations/coronavirus-covid-19-spread-map/. Even after the sharp increase in cases in rural areas in June and July, two-thirds of all counties had reported fewer than ten deaths (calculated from county-level data as of August 9, 2020).

${ }^{4}$ The 'others' may be distant others, as in the 'we're not New York' comment; but they may also be proximate others. This was illustrated in early May by the offhand remark of the Wisconsin Supreme Court Chief Justice during arguments over the legality of the extension of the state's emergency 'Safer at Home' order. When an attorney for the governor, defending the extension of the order, noted the huge surge in cases in Brown County, the Chief Justice observed that the surge was 'due to the meatpacking, though... It wasn't just the regular folks in Brown County' (Flynn 2020). The outbreaks had indeed burgeoned in Green Bay's meatpacking plants, where the workforce is composed disproportionately of immigrants, refugees, and other minorities. Apart from its offensiveness, the contrast between the meatpacking plants and 'regular folks' was medically disconcerting, overlooking the interdependence that is at the core of infectious disease epidemiology, at least for a disease as easily transmissible as Covid 19.
} 
lockdown protesters could easily draw, at least implicitly, on the longstanding and of course deeply racialized populist trope that contrasts the morally, politically, and even biomedically healthy 'heartland' (Taggart 2000, chapter 8) - the 'real' America of locally rooted communities and virtuous, hard-working ordinary citizens - with the big cities, seen as sites of corruption, criminality, and disease, and understood as dominated by liberal cosmopolitan elites on the one hand and by racial, ethnic, religious, sexual, and gender minorities on the other. The massive protests in cities across the country in late May and June - and especially the days during which police clashed with protesters, looting was widespread, and the National Guard was mobilized no doubt made that trope even more accessible.

The virus has of course come to the heartland, and the summer and fall hotspots have been precisely in the heartland. But Covid-19 has come to the heartland in a manner very different from its dramatic spread in New York in late March and early April. In New York City, at the peak, estimates suggest that $15 \%$ of the population may have been infected at the same time. At the peak of the summer surge in Arizona, Texas, and Florida, by contrast, about 5\% of the population may have been infected; and a higher fraction of those infected during the summer surge have been younger and less likely to be seriously ill. This has again created a gap between everyday experience - even in the hotspots, many people may not know anyone who has been seriously ill - and expert warnings (Silver 2020). ${ }^{5}$

The epistemic gap between local experience and expert knowledge also has a temporal aspect. Epidemiological time is exponential time. Given an easily transmissible pathogen and a

\footnotetext{
${ }^{5}$ Estimates of those infected at peak moments are taken from https://covid19-projections.com/, as of August 11, 2020. The estimates are updated as new information becomes available; as a result, estimates of the numbers infected on these peak dates may change.
} 
high effective reproduction number, a small outbreak can quickly become a disaster. The urgency of expert warnings and the case for the stringent distancing depended on this exponential temporality. Yet precisely because the warnings were taken seriously in March, they could become self-discrediting, since the lockdowns suspended exponential temporality, and the projected catastrophe never happened. This is what is sometimes called the paradox of prevention: measures taken to avert an outcome, if they are successful, can be seen in retrospect as having been unnecessary. The dire warnings had of course been conditional: if no steps were taken, then hospitals would be overwhelmed, and deaths would soar. But this is easily overlooked, whether intentionally or unintentionally. Here, too, the gap between local experience and expert projections has bred suspicion and distrust of expertise. This makes it harder for expert warnings to be taken seriously the second time around.

I turn now to the participatory challenge to expertise. Here expertise is challenged not on the terrain of everyday experience and common sense, but on the terrain of data. The participatory challenge feeds off the hyper-accessibility of expertise. By hyper-accessibility I don't of course mean that it is easy to acquire expertise, however that slippery term is defined. I mean rather that, thanks to digital hyperconnectivity, expert opinions, expert models and projections, expert research, and expertise-relevant data are more accessible and more abundant than ever.

Experts have not simply advised governments; they have also been keen to address the public. They have sought to build support for disruptive distancing measures, but they have also sought to enlist the public in altering their behavior, and thereby in altering the course of the event they seek to model. Epidemiological knowledge, once it is communicated to the public, 
enters recursively into the socio-medical reality that epidemiological models seek to grasp. The remarkable career of the 'flatten the curve' meme is perhaps the most striking example.

Experts have addressed the public both directly, through op-ed contributions, interviews, podcasts, and Twitter posts, and indirectly, by talking extensively with journalists. Their views, along with journalists' simplifying accounts of those views, have then been recirculated at high velocity - though often of course in fragmented and distorted form - by legions of digitally active lay users.

But it is not only expert opinions that are hyper-accessible; it is also the raw materials on the basis of which expert opinions are formed and revised: the projections, the research findings, and the public health data. There is an enormous glut of data and research findings. Numerous tracking projects convey daily updates and trends on cases, deaths, tests, and hospitalizations. Many of these allow users to download the raw data, so data-sophisticated users can easily explore the data on their own. Equally accessible are the numerous forecasting undertakings, which seek to predict future trajectories of cases, deaths, and hospitalizations. And voluminous streams of new research are freely accessible on preprint servers - not only published work, but also (indeed primarily, in this context) papers that have not yet been peer-reviewed. Already by early May, about 3,000 papers on Covid-19 had been posted on bioRxiv and medRxiv (Kwon 2020), and several not yet peer-reviewed papers have been drawn into public debates in highly contentious ways (Heimstädt 2020; Bajak and Howe 2020).

I want to underscore two implications of the hyper-accessibility and superabundance of Covid-related expertise, research, and data. One is the proliferation of the means of assessing expertise. For what is accessible in the digital public sphere - or what appears to be accessible is not only the content of expert opinion but also the evidence that supports or undermines it. It's 
easy to find data or new research that can be taken (or of course mistaken) as suggesting, or even 'proving,' as some would claim, that 'the experts' got it wrong in this way or that. For example, it's easy to cite research and numbers that suggest that Covid-19 is much less dangerous than 'the experts' claimed, indeed no more dangerous than the seasonal flu. And it's easy, therefore, to claim that the lockdown was a catastrophic mistake - the 'greatest mistake in history,' as one commentator rather grandly put it (Prager 2020). Yet the hyper-accessibility and superabundance of expertise and research also make it easy to come to what is in a sense the opposite (and equally problematic) conclusion: that ‘the experts' don’t agree on anything. In both respects, hyper-accessibility and superabundance can contribute to undermining the credibility of expertise. ${ }^{6}$

The second implication is the ease of claiming and exercising expertise, or at least some kind of quasi-expertise. Semi-experts, quasi-experts, pseudo-experts, and lay experts have proliferated. And even if it's not easy to claim expertise per se, it's at least easy to claim the right to join in, as a knowledgeable participant, in the collective public effort to interpret and define socio-medical reality. As prominent lockdown skeptic Aaron Ginn (2020), a selfdescribed Silicon Valley 'growth hacker,' put it, 'I'm quite experienced at understanding virality, how things grow, and data... Data is data. Our focus here isn’t treatments but numbers. You don’t need a special degree to understand what the data says and doesn't say. Numbers are universal.'

\footnotetext{
${ }^{6}$ The hyper-accessibility of expertise also makes it easy to track sharp shifts in expert opinion on such matters as the seriousness of the threat, the appropriateness of travel restrictions, and the importance of masks. This too can weaken the credibility of experts (Shulman, 2020). In the case of masks, it's not so much that expert opinion shifted dramatically as that public health messaging was appallingly paternalistic, confusing, and counterproductive (Tufekci 2020).
} 
Ginn’s epistemologically populist claim to a seat at the table did not go unchallenged. His essay contesting the case for the lockdown racked up more than 2.5 million views on Medium in 24 hours, but it was removed by the platform after a scathing critique from a prominent biologist (Bergstrom 2020). This was one of many interventions to have been 'invisibilized' by major platforms. Concerns have been mounting in recent years about the proliferation of misinformation and disinformation in the structurally flat, unmediated, and in that sense populist digital public sphere (Brubaker 2017a), in which visibility is driven by algorithmically amplified popularity (Gillespie 2016). Those concerns have intensified during the pandemic. In response, major platforms have been aggressively removing or flagging content deemed potentially harmful from a public health standpoint. But aggressive and highly visible content moderation - would-be readers or viewers are confronted with messages like 'this post is under investigation or was found in violation of the Medium Rules' or 'this video has been removed for violating YouTube's Community Guidelines’ - has raised concerns about censorship and generated an epistemologically populist backlash. The removal of Ginn’s essay, for example, prompted a Wall Street Journal article (Finley 2020) that raised Ginn’s profile among lockdown skeptics, who could complain with good reason - at least in the early phase of the lockdown - that major digital platforms were colluding in restricting the range of what they deemed to be legitimate views.

The participatory challenge to expertise - part of a broader "participatory turn" in politics, culture, and society (Mede and Schäfer, 2020: 5-6) - is not new. It has roots in longterm developments in the cultural politics of knowledge. These include the decline of what might be called epistemic deference; the long-standing suspicion of insular forms of expert judgment; the valorization of various forms of lay expertise (Epstein 1995; Callon 1999; Prior 2003); and 
the growing sense - especially in health and lifestyle domains - that people must educate themselves and take responsibility for arbitrating between competing expert claims (Reich 2016). But the pandemic and the flood of data it has unleashed have given a major new impetus to this participatory challenge and further destabilized expertise.

The crisis of expertise is systemic and long-standing. It results not only from the participatory challenge, but also from the unavoidable politicization of expertise that follows from its pervasive implication in regulatory decision-making that invariably has redistributive consequences (Eyal 2019: 97). Yet beyond this chronic crisis of expertise - if the oxymoron is allowed - Covid-19 confronts us with a more specific epistemic crisis, a crisis of public knowledge (Brubaker 2017a).

It is not only that 'normal science' cannot cope with a situation in which 'facts are uncertain, stakes high, values in dispute and decisions urgent' (Waltner-Toews et al 2020). It is also that we inhabit radically different public worlds. The public worlds we inhabit are constituted in significant part by what we know or believe about them. And what we know or believe about Covid-19 - not only about what should be done, but about what is the case - is radically discrepant. There is no shared definition of the situation. Is Covid-19 is 'the greatest existential threat in our lifetimes' (New York Times Editorial Board 2020), or is it no more dangerous than a bad flu season? Did the lockdowns save more than 3 million lives in Europe (Achenbach and Meckler, 2020)? Or were not only medically ineffective and economically catastrophic but likely to have disastrous health consequences, especially in poor countries, disrupting vaccination programs and possibly even tipping already vulnerable populations into mass starvation (Gorvett 2020)? Is a targeted strategy of protecting the vulnerable while allowing others to resume normal life the best way of minimizing mortality and social harm, as 
proposed in the Great Barrington Declaration (Kulldorff et al., 2020)? Or would adopting this strategy be tantamount to 'mass murder', as one critic not too subtly argued on CNN (Barry 2020)?

\section{Crisis}

I turn now, much more briefly, to crisis. Populism thrives on crisis, even depends on crisis. Yet crises are not pre-given; they are made, construed, and performed. "Crisis" is not a neutral category of social analysis; it is a category of social and political practice, mobilized to do specific political work. The rhetoric of "crisis" serves as a bid for attention, a marker of urgency, a claim that extraordinary times require extraordinary measures. Populists do not simply respond to pre-existing crises; they seek rather to cultivate, exacerbate, or even create a sense of crisis, casting the crisis as one that they alone have the power to resolve. Crisis is therefore not prior to and independent of populist politics; rather, performances of crisis are often a central part of populist politics (Moffitt, 2016; Stavrakakis et al., 2018) - though not of course of populist politics alone. With the complicity of mainstream, alternative, and social media, populist and other political actors invoke, construct, intensify, dramatize, and in these ways contribute to producing the very crises to which they claim to respond.

Yet the pandemic has occasioned a curious reversal. It is now populists who have been accusing mainstream politicians and media - and of course public health experts as well - of blowing the Corona crisis out of all proportion or even of creating it as a crisis. It's true that some populist leaders in power - including notably Hungary’s Viktor Orbán, Serbia’s Aleksandr Vučić, and India's Narendra Modi (Jaffrelot and Martelli, 2020) - have embraced the rhetoric of crisis and used it to justify emergency measures that have tightened their authoritarian grip on power. In opposition, however, the dominant populist tendency has been to downplay the 
seriousness of the pandemic and to turn the tables by accusing incumbents - in the American context, primarily Democratic state governors, who have taken the strongest steps to restrict activities in the name of public health - of exploiting or inventing the corona crisis in order to illegitimately expand state power, suspend rights, and deepen surveillance. (Some populists in power have also downplayed the seriousness of the pandemic, most notoriously Brazil's Jair Bolsonaro (Lasco 2020), though Trump and some others have done so as well, if not so consistently.)

The paradox, then, is that instead of performing crisis, as is generally the case, populism has seemed here to be performing non-crisis, performing normality in the face of an establishment in full crisis mode. But the paradox is again only apparent. Populists have in fact been seeking to capitalize on crisis. But the crisis on which they have been seeking to capitalize is the economic crisis, not the medical crisis. And because of the unevenness of the pandemic, the economic crisis has seemed much more threatening to many people than the medical crisis.

Anti-lockdown protesters also sought to stage and provoke a political crisis. The emergency regulations issuing from the overblown medical crisis, in their view, created a genuine political crisis. This was cast as a crisis of governmental overreach that trampled on fundamental rights, including the right to work, the right to open one's business, the right to move in public space, the right to free exercise of religion, the right to bear arms, the right to protest (Abrams and Langford 2020), the right to privacy, and the right not to wear a mask (Finn, 2020; Parshley 2020). Protesters, some of them armed, freely invoked the language of tyranny and appealed to constitutional rights (Beckett, 2020; Chabria, 2020; Fernandez and Montgomery, 2020). The staging of this crisis, among other things, provided a golden opportunity for the violently antigovernment Boogaloo movement, which seized on the fiercely anti-government animus of the 
anti-lockdown protests - and which has subsequently, if improbably, sought to seize on the protests against police brutality as well - in order to move out of the shadows and recruit new followers (Evans and Wilson, 2020; Kunzelman, 2020).

The progressive easing of the spring lockdown weakened protesters' efforts to provoke a political crisis along these lines. And the political crisis they sought to provoke was overtaken in June by another, broader political crisis. But the two crises are not unrelated, and the new crisis has in some ways hardened the anti-government stance that animated the populist effort to stage a crisis of government overreach. Anger at continuing restrictions on church services, for example - restrictions that were upheld by the Supreme Court at the end of May, as the protest wave was gathering force (Liptak 2020) - was reinforced by the spectacle of huge crowds marching in the streets (Shrier 2020).

\section{Protection}

I turn finally to the paradox of protection. We think of populism as protectionist. In recent years this has meant claiming to protect 'the people' - economically, demographically, culturally, and physically - from threats arising from unchecked globalization, the neoliberal economy, open borders, and cosmopolitan culture, all seen as favored by economic, political, and cultural elites (Brubaker 2017b).

Yet faced with the coronavirus, populism been anti-protectionist. Populists have taken the side of openness against closure, and they have challenged what they see as the overprotective nanny state. They have cast the lockdowns as hysterical overreactions, criticized paths to reopening as overcautious, and sometimes challenged social distancing protocols as unnecessary. 
The paradox is heightened by the fact that conservatives (and American anti-lockdown protesters, unlike their counterparts in the first wave of anti-lockdown protests in Germany, have been overwhelmingly conservative) generally tend to be more sensitive than liberals to signs of threat and danger, including ‘threat[s] of germs and contamination' (Haidt 2013: 279; Klein 2020). And indeed early in the pandemic, when the virus was perceived as an outside threat, conservative and far-right figures had taken the lead in pressuring Trump to ban travel from China, at a time when liberals and public health officials questioned that measure (Thielking and Facher 2020).

One might argue that the paradox of protection, like the others, is only an apparent paradox. One might argue, for example, that the populism of lockdown opponents has indeed been protectionist, but that it has focused on protecting livelihoods and liberties rather than lives. But I don't think this is quite right. The demand to restore individual liberties, in the context of emergency restrictions, is a libertarian argument; I don't think it can plausibly be characterized as protectionist. Economic demands could be framed in protectionist terms, for example as a demand for state action to protect jobs, or to protect people from losing their health insurance or from being evicted from their homes. But this argument has not been made by anti-lockdown protesters.

So I think there is a real paradox here, or at least a puzzle. Why has populism turned antiprotectionist during the pandemic? Part of the answer, I think, is that populism - unlike socialism, liberalism, or conservativism - is not a substantive political ideology. It is substantively empty. Populism is relational and oppositional, defined by what it opposes. What it opposes is formally always the same - it is always anti-elite, always anti-establishment - but 
substantively variable, depending on how the opposition between 'the people' and 'the elite' or 'the establishment' is constructed (Canovan 1999).

Populism in the global north has indeed been strongly protectionist in recent decades. This made political sense in a context of hyper-globalization and hegemonic neoliberalism, in which economic, political, and cultural elites could plausibly be seen as indifferent to the bounded solidarities of community and nation. But today there is no political profit in a protectionist critique of the status quo, since closed borders, re-nationalization, and deglobalization are the status quo.

But if populism could not at present take a distinctively protectionist stance vis-à-vis the outside world, since the protectionist space was already occupied, it could take a distinctively anti-protectionist stance vis-à-vis the domestic protectionist regime. The regime of protection has been characterized in populist terms as a project of political, cognitive, public health, mainstream media, and professional elites. These elites - so runs the critique - have been at most inconvenienced by the regime of protection. They can work from home, and they continue to draw their salaries. They can afford the luxury of hyper-protection; they can afford to minimize the risk of contagion at the expense of everything else.

On this account, 'the people' cannot afford the luxury of lockdown-level hyperprotection. But the populist claim is also that 'the people' don't need or want this degree of protection. Gendered imagery, which is often central to populism (Löffler et al., 2020), comes into play here as well. 'The people' are seen as tough, resilient, brave, and willing to take risks, the elite as soft, coddled, anxious, oversensitive, and risk-averse. Gender symbolism is also central to the cultural politics of masks (Glick, 2020), though of course the performance of 
unmasked virility forgets that masks are much less about protecting oneself than about protecting others.

Protectionist elites have also been resented during the pandemic for their moralizing, scolding, and school-teacherish stance. They have been cast in populist terms as all too eager to lecture ordinary people about how they should behave and all too ready to reprimand them for their selfish heedlessness of others when they have violated social distancing guidelines. Since protectionist elites have invoked the authority of science, the sudden pivot of many in June to applauding mass protests and minimizing their public health risks - or justifying those risks by appealing to a greater good - was easily seen by populists as undermining their authority and credibility. The pivot was especially disorienting when it was made by public health experts, as in the open letter signed by a large group of public health and infectious disease professionals, arguing that 'as public health advocates, we do not condemn these gatherings as risky for Covid19 transmission' but rather 'support them as vital to the national public health and to the threatened health specifically of Black people in the United States' (Diamond 2020; Palus 2020). ${ }^{7}$

Populist skepticism of Corona-protectionism aligns with a broader popular skepticism of what is seen as elite overprotectiveness in culture, education, and everyday life. This is a skepticism toward what one prominent book (Lukianoff and Haidt 2018) has called 'safetyism,' referring to the efforts of anxious parents to protect their children from even the most minimal risks and to the demand for 'safe spaces,' and for the protection of students' feelings, in

\footnotetext{
7 The open letter can be found at https://drive.google.com/file/d/1Jyfn4Wd2i6bRi12ePghMHtX3ys1b7K1A/view
} 
American universities. Populist opposition to Corona protectionism may have drawn some of its energy from this broader current of skepticism.

\section{Conclusion}

The pandemic has not generated a coherent or large-scale populist response. But the spring lockdowns and the ongoing restrictions on activities have created a reservoir of popular anger, and they have fostered the emergence of a populist mood among substantial parts of the population. They have heightened distrust of expertise, exacerbated antipathy to intrusive government regulation, and amplified skepticism toward elite overprotectiveness.

Critics of Corona restrictions have sought to bring together these forms of proto-populist discontent in a counter-narrative according to which misguided and out-of-touch experts, powerhungry regulators, and excessively risk-averse elites have combined to wreck the economy, destroy livelihoods and trample on liberties. This narrative has found considerable traction online, but it has not (yet) gained broad public support. Substantial majorities, for example, continue to favor mask requirements and are more concerned about controlling the virus than about resuming unimpeded economic activity.

Still, the present moment remains fraught, not least because the dynamics of medical, economic, political, and epistemic crises interpenetrate in complex and largely unforeseeable ways. The future course of the pandemic, for example, itself depends on many complexly interacting processes. Among these (in addition to the development of treatments and vaccines, themselves deeply drawn into partisan political struggles) are what people believe or know about 
the pandemic, and how they act on that knowledge - whether they wear masks, for example, and whether and how they practice physical distancing - as well as what decisions are taken about modalities and timing of reopening. But what people believe or know about the pandemic is shaped by chaotic and shifting public messaging, embedded in a polarized media ecosystem, and colored by the challenges to expertise that I have described. And how they act depends not only on what they think or know but also on social pressures and expectations in their immediate environment. Decisions about modalities and timing of reopening, for their part, respond both to contested knowledge about the dynamics of the pandemic and to political pressures generated by the economic crisis and filtered through the prism of hyper-polarized partisan politics.

As a result of these and other interacting processes, the curve of new infections turned sharply upward in June and July and has recently been rising again. This has generated new claims to knowledge and new pressures for action. But these knowledge claims remain deeply contested and beset with deep uncertainty. They yield no unambiguous and uncontested guidelines for action. The crisis of expertise has continued to deepen, as has the political crisis over how to respond to the pandemic, in the context of an approaching election and of massive political pressure on public health agencies like the Center for Disease Control and the Food and Drug Administration. And this of course only begins to scratch the surface of the complex interpenetration of medical, economic, political, and epistemic crises. We should not complacently assume that the past is a good guide to the future. We are truly in uncharted territory.

\section{Acknowledgments}

I thank Alexander Ferrer for research assistance and Zsolt Boda, Ben Brubaker, Elizabeth Brubaker, Craig Calhoun, Zsuzsa Csergő, and Bill Heffernan for comments and criticisms. 
Thanks also to Inger Furseth of the University of Oslo and Margit Feischmidt of the Center for

Social Sciences, Hungarian Academy of Sciences for arranging the webinars in which earlier versions of this essay were presented.

\section{References}

Abrams F and Langford J (2020) The Right of the People to Protest Lockdown. The New York Times, 19 May. https://www.nytimes.com/2020/05/19/opinion/coronavirus-firstamendment-protests.html .

Achenbach J and Meckler L (2020) Shutdowns prevented 60 million coronavirus infections in the U.S., study finds. Washington Post, 8 June. https://www.washingtonpost.com/health/2020/06/08/shutdowns-prevented-60-millioncoronavirus-infections-us-study-finds/

Bajak A and Howe J (2020) A Study Said Covid Wasn't That Deadly. The Right Seized It. The New York Times, 14 May. https://www.nytimes.com/2020/05/14/opinion/coronavirusresearch-misinformation.html .

Barry JM (2020) Herd Immunity? Or ‘Mass Murder’? The New York Times, 19 October. Available at: https://www.nytimes.com/2020/10/19/opinion/coronavirus-herdimmunity.html

Beckett L (2020) Armed protesters demonstrate against Covid-19 lockdown at Michigan capitol. The Guardian, 30 April. Available at: https://www.theguardian.com/usnews/2020/apr/30/michigan-protests-coronavirus-lockdown-armed-capitol

Bergstrom C (2020). Twitter thread, March 21. https://twitter.com/CT_Bergstrom/status/1241522140559503360

Brandmayr F (2019) Public Epistemologies and Intellectual Interventions in Contemporary Italy. International Journal of Politics, Culture, and Society. DOI: 10.1007/s10767-019-09346-3.

Brubaker R (2017a) Forget Fake News. Social Media Is Making Democracy Less Democratic. Zócalo Public Square, 29 November. https://www.zocalopublicsquare.org/2017/11/29/forget-fake-news-social-media-makingdemocracy-less-democratic/ideas/essay/

Brubaker R (2017b) Why populism? Theory and Society 46(5): 357-385. DOI:10.1007/s11186017-9301-7.

Brubaker R (2020) Populism and nationalism. Nations and Nationalism 26(1): 44-66. 
Callon M (1999) *The Role of Lay People in the Production and Dissemination of Scientific Knowledge. Science, Technology and Society 4(1): 81-94. DOI: 10.1177/097172189900400106.

Canovan M (1999) Trust the People! Populism and the Two Faces of Democracy. Political Studies 47(1): 2-16. DOI: 10.1111/1467-9248.00184.

Chabria A (2020) ‘Freedom’ protest against coronavirus orders leads to arrests at California Capitol. Los Angeles Times, 1 May. Available at: https://www.latimes.com/california/story/2020-05-01/crowd-protests-coronaviruslockdown-sacramento-california-capitol.

Diamond D (2020) Suddenly, Public Health Officials Say Social Justice Matters More Than Social Distance. Politico, 4 June. https://www.politico.com/news/magazine/2020/06/04/public-health-protests-301534

Epstein S (1995) The Construction of Lay Expertise: AIDS Activism and the Forging of Credibility in the Reform of Clinical Trials: Science, Technology, \& Human Values 20(4). Sage PublicationsSage CA: Thousand Oaks, CA: 408-437. DOI: 10.1177/016224399502000402.

Evans R and Wilson J (2020) The Boogaloo Movement Is Not What You Think. bellingcat, 27 May. https://www.bellingcat.com/news/2020/05/27/the-boogaloo-movement-is-not-whatyou-think/.

Eyal G (2019) The Crisis of Expertise. Cambridge, UK ; Medford, MA: Polity Press.

Eyal G (2020) Structural Shocks and Extreme Exposures - covid-19 is a make or break moment for u.s. experts. Contexts, 6 April. https://contexts.org/blog/structural-shocks-and-extremeexposures/.

Fernandez M and Montgomery D (2020) Businesses Chafing Under Covid-19 Lockdowns Turn to Armed Defiance. The New York Times, 13 May. https://www.nytimes.com/2020/05/13/us/coronavirus-businesses-lockdown-guns.html.

Finley A (2020) The Lockdown Skeptic They Couldn't Silence. Wall Street Journal, 15 May. https://www.wsj.com/articles/the-lockdown-skeptic-they-couldnt-silence-11589566245/

Finn JE (2020) The Constitution doesn't have a problem with mask mandates. Available at: http://theconversation.com/the-constitution-doesnt-have-a-problem-with-mask-mandates$\underline{142335 .}$.

Flynn M (2020) Wisconsin chief justice sparks backlash by saying covid-19 outbreak is among meatpacking workers, not 'the regular folks'. Washington Post, 7 May. 
https://www.washingtonpost.com/nation/2020/05/07/meatpacking-workers-wisconsincoronavirus/

Gillespie T (2016) \#trendingistrending : when algorithms become culture. In: Seyfert R and Roberge J (eds) Algorithmic Cultures: Essays on Meaning, Performance and New Technologies. London; New York: Routledge, Taylor \& Francis Group, pp. 52-75.

Ginn A (2020) COVID-19 - Evidence Over Hysteria. Zero Hedge, 21 March. https://www.zerohedge.com/health/covid-19-evidence-over-hysteria .

Glick P (2020) Masks and Emasculation: Why Some Men Refuse to Take Safety Precautions. In: Scientific American Blog Network. 30 April. https://blogs.scientificamerican.com/observations/masks-and-emasculation-why-some-menrefuse-to-take-safety-precautions/

Gorvett Z (2020) Why most Covid-19 deaths won't be from the virus. BBC Future, 28 May. https://www.bbc.com/future/article/20200528-why-most-covid-19-deaths-wont-be-fromthe-virus.

Haidt J (2013) The Righteous Mind: Why Good People Are Divided by Politics and Religion. New York: Vintage Books.

Heimstädt M (2020) Between fast science and fake news: preprint servers are political. LSE Research Online, 3 April. http://eprints.lse.ac.uk/104358/.

Jaffrelot C and Martelli JT (2020) Current crisis consolidates populist rapport between a leader and a fictional representation of people. The Indian Express, 29 April. https://indianexpress.com/article/opinion/columns/india-covid-19-coronavirus-lockdownnarendra-modi-6383721/.

Klein E (2020) Why are liberals more afraid of the coronavirus than conservatives? Vox, 21 May. https://www.vox.com/2020/5/21/21262329/coronavirus-liberals-conservatives-pollsafraid-psychology-distacing.

Kulldorff M, Gupta S and Bhattacharya J (2020) Great Barrington Declaration. Available at: https://gbdeclaration.org/

Kunzelman M (2020) Virus restrictions fuel anti-government ‘boogaloo' movement. AP NEWS, 13 May. https://apnews.com/3783a0cdc0e6cc04b43fd28b6069e960.

Kwon D (2020) How swamped preprint servers are blocking bad coronavirus research. Nature 581(7807): 130-131. DOI: 10.1038/d41586-020-01394-6.

Lasco G (2020) Medical populism and the COVID-19 pandemic. Global Public Health 0(0). Taylor \& Francis: 1-13. DOI: 10.1080/17441692.2020.1807581. 
Liptak A (2020) Supreme Court, in 5-4 Decision, Rejects Church’s Challenge to Shutdown Order. The New York Times, 30 May. https://www.nytimes.com/2020/05/30/us/supremecourt-churches-coronavirus.html.

Löffler M, Luyt R and Starck K (2020) Political masculinities and populism. NORMA 15(1). Routledge: 1-9. DOI: 10.1080/18902138.2020.1721154.

Lukianoff G and Haidt J (2018) The Coddling of the American Mind: How Good Intentions and Bad Ideas Are Setting up a Generation for Failure. New York: Penguin Press.

Mede NG and Schäfer MS (2020) Science-related populism: Conceptualizing populist demands toward science. Public Understanding of Science. SAGE Publications Ltd:

0963662520924259. DOI: $10.1177 / 0963662520924259$.

Moffitt B (2016) The Global Rise of Populism: Performance, Political Style, and Representation. Stanford University Press.

New York Times Editorial Board (2020) The Most Patriotic Thing You Can Do Right Now. The New York Times, 24 May. https://www.nytimes.com/2020/05/24/opinion/coronavirusus.html.

Palus S (2020) Public Health Experts Say the Pandemic Is Exactly Why Protests Must Continue. Slate Magazine, 2 June. https://slate.com/technology/2020/06/protests-coronaviruspandemic-public-health-racism.html.

Parshley L (2020) Doctors' new coronavirus threat: Patients who refuse to wear masks. Vox, 21 May. https://www.vox.com/2020/5/21/21266413/coronavirus-face-masks-trump-cdc-n95.

Prager D (2020) The Worldwide Lockdown May Be the Greatest Mistake in History. Townhall, 5 May. https://townhall.com/columnists/dennisprager/2020/05/05/the-worldwide-lockdownmay-be-the-greatest-mistake-in-history-n2568180.

Prior L (2003) Belief, knowledge and expertise: the emergence of the lay expert in medical sociology. Sociology of Health \& Illness 25(3): 41-57. DOI: 10.1111/1467-9566.00339.

Reich JA (2016) Calling the Shots: Why Parents Reject Vaccines. New York: New York University Press.

Saurette P and Gunster S (2011) Ears Wide Shut: Epistemological Populism, Argutainment and Canadian Conservative Talk Radio. Canadian Journal of Political Science 44(01): 195-218. DOI: $10.1017 /$ S0008423910001095. 
Schulman A (2020) The Coronavirus and the Right's Scientific Counterrevolution. The New Republic, 15 June. Available at: https://newrepublic.com/article/158058/coronavirusconservative-experts-scientific-counterrevolution

Shrier A (2020) Politicians Shutter Churches and Synagogues, Then Tolerate Riots. Wall Street Journal, 5 June. https://www.wsj.com/articles/politicians-shutter-churches-and-synagoguesthen-tolerate-riots-11591376851.

Silver, N (2020). Twitter thread, June 10. https://twitter.com/NateSilver538/status/1270697442481143809

Stavrakakis Y, Katsambekis G, Kioupkiolis A, et al. (2018) Populism, anti-populism and crisis. Contemporary Political Theory 17(1): 4-27.

Taggart PA (2000) Populism. Buckingham, England; Philadelphia, Pa: Open University Press.

Thielking M and Facher L (2020) Health experts warn China travel ban would hinder coronavirus response. STAT, 31 January. https://www.statnews.com/2020/01/31/as-farright-calls-for-china-travel-ban-health-experts-warn-coronavirus-response-would-suffer/.

Tufekci Z (2020) Why Telling People They Don’t Need Masks Backfired. The New York Times, 17 March. Available at: https://www.nytimes.com/2020/03/17/opinion/coronavirus-face$\underline{\text { masks.html }}$

Waltner-Toews D, Biggeri A, Marchi BD, et al. (2020) Post-normal pandemics: Why COVID-19 requires a new approach to science. STEPS Centre, 25 March. https://stepscentre.org/blog/postnormal-pandemics-why-covid-19-requires-a-new-approach-to-science/.

Washington Post-Ipsos (2020) Online Poll: April 27, 2020 - May 4, 2020. Ipsos Knowledge Panel, Poll, May. https://contextcdn.washingtonpost.com/notes/prod/default/documents/7a39185f-8222-4e28-95285741ebb137ad/note/18ba2687-26bf-46ba-bd52-fad38afc4000.\#page=1

Ylä-Anttila T (2018) Populist knowledge: 'Post-truth' repertoires of contesting epistemic authorities. European Journal of Cultural and Political Sociology 5(4): 356-388. 